\title{
Effectiveness of Vitamin D and Vitamin B Supplementation Therapy in Diabetic Neuropathic Pain Standard Therapy
}

\author{
Rizaldy T. Pinzon ${ }^{1,2}$, Yohana R. T. D. Christi ${ }^{2}$ \\ ${ }^{1}$ Bethesda Hospital Yogyakarta, Yogyakarta, Indonesia, \\ ${ }^{2}$ Faculty of Medicine, Duta Wacana Christian University School of Medicine, Yogyakarta, Indonesia
}

\begin{abstract}
The chronic complication from diabetes mellitus (DM) is painful diabetic neuropathy, and the treatment with standard therapy is inefficient. Furthermore, vitamin B combination is effective as a neuropathy treatment due to nerve repair acceleration by enhancing regeneration and restoring function, while individuals with type $2 \mathrm{DM}$ are inseparable from vitamin D deficiency. This study aimed to measure diabetic neuropathy pain reduction in patients with type $2 \mathrm{DM}$ by administration of additional vitamin $\mathrm{D}$ to standard therapy. This was a quasi-experimental study employing non-equivalent control group method on 77 patients selected using consecutive sampling at Bethesda Hospital Yogyakarta between December 2019 and February 2020. In addition, the subjects consisted of 48 men and 29 women, and were divided into 4 therapy groups executed within 1-3 months comprising (I) symptomatic therapy only; (II) symptomatic combination therapy with vitamin B; (III) symptomatic combination therapy with vitamin D; and (IV) symptomatic combination therapy with vitamin B-vitamin D. The pain assessment employed Visual Analogue Scale (VAS) prior and after administration, and demographic characteristics data between the 4 groups lacked noteworthy differences. The results indicated decreased pain intensity after therapy with the mean VAS in group I from $53.36 \pm 14.65$ to $42.27 \pm 17.16$, group II from $50.56 \pm 12.11$ to $13.89 \pm 14.61$, group III from $50.77 \pm 15.98$ to $19.23 \pm 18.09$, and group IV from $54.55 \pm 16.35$ to $7.27 \pm 6.47$. However, group administered with symptomatic combination therapy with vitamin D revealed higher significant improvement, while substantial pain intensity reduction was indicated from symptomatic therapy combined with vitamin B and vitamin $\mathrm{D}$.
\end{abstract}

Keywords: Combination of vitamin D, pain intensity, painful diabetic neuropathy

\section{Efektivitas Pemberian Terapi Tambahan Vitamin D dan Vitamin B pada Terapi Standar Nyeri Neuropati Diabetik}

\begin{abstract}
Abstrak
Neuropati diabetik merupakan salah satu komplikasi kronis yang sering terjadi dari penyakit diabetes melitus (DM). Pengobatan neuropati diabetik dengan terapi simptomatik hingga sekarang belum mencapai target. Vitamin B kombinasi efektif sebagai pengobatan neuropati karena mempercepat perbaikan saraf dengan meningkatkan regenerasi saraf dan memulihkan fungsi saraf. Pasien DM tipe 2 tak lepas dari keadaan defisiensi vitamin D. Penelitian ini bertujuan untuk mengukur penurunan nyeri neuropati diabetik pada pasien DM tipe 2 yang diberi terapi tambahan vitamin D terhadap terapi standar. Penelitian ini merupakan penelitian quasi-experimental dengan metode non equivalent control group kepada 77 pasien yang terpilih berdasarkan consecutive sampling di Rumah Sakit Bethesda Yogyakarta pada bulan Desember 2019-Februari 2020.Subjek dibagi menjadi 4 kelompok pemberian terapi yaitu kelompok yang diberi (1) terapi simptomatik saja, (2) terapi simptomatik kombinasi vitamin B, (3) terapi simptomatik kombinasi vitamin D, dan (4) terapi simptomatik kombinasi vitamin B-vitamin D. Pemberian terapi dilakukan dalam waktu 1-3 bulan. Penilaian nyeri menggunakan Visual Analogue Scale (VAS) sebelum diberikan terapi dan setelah pemberian terapi. Subjek terdiri dari 48 orang laki-laki dan 29 orang perempuan. Data karakteristik demografi di antara 4 kelompok tidak memiliki perbedaan yang bermakna. Hasil penelitian menunjukkan adanya penurunan intensitas nyeri dengan rata-rata VAS kelompok I sebelum terapi 53,36 $\pm 14,65$ menjadi $42,27 \pm 17,16$ setelah terapi, kelompok II dari 50,56 $\pm 12,11$ menjadi $13,89 \pm 14,61$, kelompok III dari

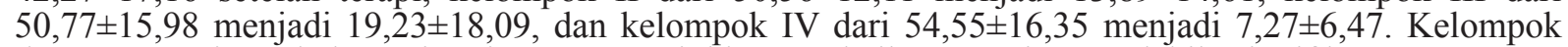
dengan terapi tambahan vitamin D menunjukkan perbaikan nyeri yang lebih signifikan. Penurunan intensitas nyeri neuropati diabetik secara signifikan ditemukan pada pemberian terapi simptomatik yang dikombinasikan dengan vitamin $\mathrm{B}$ dan vitamin $\mathrm{D}$.
\end{abstract}

Kata kunci: Intensitas nyeri, kombinasi vitamin D, nyeri neuropati diabetik

Correspondence: Dr. dr. Rizaldy T. Pinzon, M.Sc., Sp.S., Faculty of Medicine, Duta Wacana Christian University School of Medicine, Yogyakarta, D.I. Yogyakarta 55224, Indonesia, email:drpinzon17@gmail.com Submitted: $2^{\text {th }}$ April 2020, Accepted: $15^{\text {th }}$ October 2020, Published: $9^{\text {th }}$ December 2020 


\section{Introduction}

Indonesia ranks for the sixth for the number of diabetic mellitus (DM) patients in the world with a total of 10.3 million people in $2017 .{ }^{1}$ Complications that often arise in patients with $\mathrm{DM}$ is diabetic neuropathy (DN) or diabetic neuropathy. ${ }^{2}$ It is estimated that around 25$30 \%$ of patients with DM experience painful diabetic neuropathy (PDN). ${ }^{2}$ About $80 \%$ of DM patients with PDN complain of severe pain. $^{2}$

Vitamin B are commonly added as a treatment for neuropathy. Vitamin B combination is effective as a neuropathy treatment because it accelerates nerve repair by increasing nerve regeneration and restoring nerve function. ${ }^{3}$ Vitamin B combination is effective as a neuropathy treatment because it accelerates nerve repair by increasing nerve regeneration and restoring nerve function. ${ }^{4,5}$

$\mathrm{DM}$ is associated with a state of vitamin D deficiency. ${ }^{6}$ Study by Indra et al. explains that $49 \%$ or almost half of diabetes mellitus patients have vitamin D deficiency. ${ }^{7}$ Vitamin D deficiency can cause a deficiency of neurotropic factors, which can cause neurological damage or dysfunction that triggers neuropathy. ${ }^{8}$ Antiepileptic drugs that block calcium channels, SNRIs, and tricyclic antidepressants as first line drugs in treatment of neuropathic pain..$^{9}$ Firstline treatment for diabetic neuropathy pain has limited benefits and low level of effectiveness. ${ }^{9}$ There is no satisfactory treatment in a number of guidelines. ${ }^{10}$ Only a few symptomatic treatments for neuropathic pain have been proven effective. ${ }^{10}$

Vitamin D is an essential neurosteroid that plays a major role in the physiology of the central and peripheral nervous system. ${ }^{11,12}$ Vitamin D supplementation can help reduce pain intensity. ${ }^{13}$ Vitamin D has neurotropic effects, anti-inflammatory effects and immunoregulatory effects that play a role in pain management. ${ }^{14,15}$
The nevous system in patients with diabetes mellitus undergo a pro-inflammatory process which will cause neuropathy symptoms. ${ }^{16,17}$ The anti-inflammatory effect of vitamin D can suppress the release of pro-inflammatory cytokines and $\mathrm{T}$ cell responses. ${ }^{15}$ Vitamin D can reduce nerve threshold by inhibiting COX2 expression and stimulating 15-prostaglandin dehydrogenase (15-PGDH) which will reduce prostaglandin..$^{18}$ It is hoped that further research can make a combination of effective treatments for diabetic neuropathy pain and this study adding vitamin $\mathrm{D}$ as a treatment for diabetic neuropathic pain. ${ }^{9,10,19}$

\section{Methods}

This research is a quasi experimental research with non equivalent control group method and used prospective data taken from the patient's medical records. Subjects examined were patients with DM especially type 2 with DN pain at Bethesda Hospital Yogyakarta from December 2019 until February 2020. Subjects numbered 77 people which were divided into 4 groups and each was given therapy namely (1) symptomatic therapy (Gabapentin $100-300 \mathrm{mg}$ or amitryptilin 10-25 $\mathrm{mg}$ or pregabalin $50-75 \mathrm{mg}$ or combination) group, (2) symptomatic combination therapy with vitamin B, (3) symptomatic combination therapy with vitamin $D$, and (4) symptomatic combination therapy with vitamin B-vitamin D. Additional vitamin D therapy is given at a dose of 400 IU taken two times daily for groups 3 and 4 . The vitamin B is vitamin B combination of $100 \mathrm{mg} \mathrm{B} 1,100 \mathrm{mg} \mathrm{B} 6$, and $5000 \mathrm{mcg}$ B12 taken once daily for groups 2 and 4. Provision of therapy is carried out for 1-3 months. Each group was assessed for pain scale before and after administering therapy using Visual Analogue Scales (VAS). Data obtained from research subjects were analyzed using Kruskal-Wallis analysis and displayed in tabular form. 
Table 1 Comparison of Basic Characteristics between the Four Treatment Groups

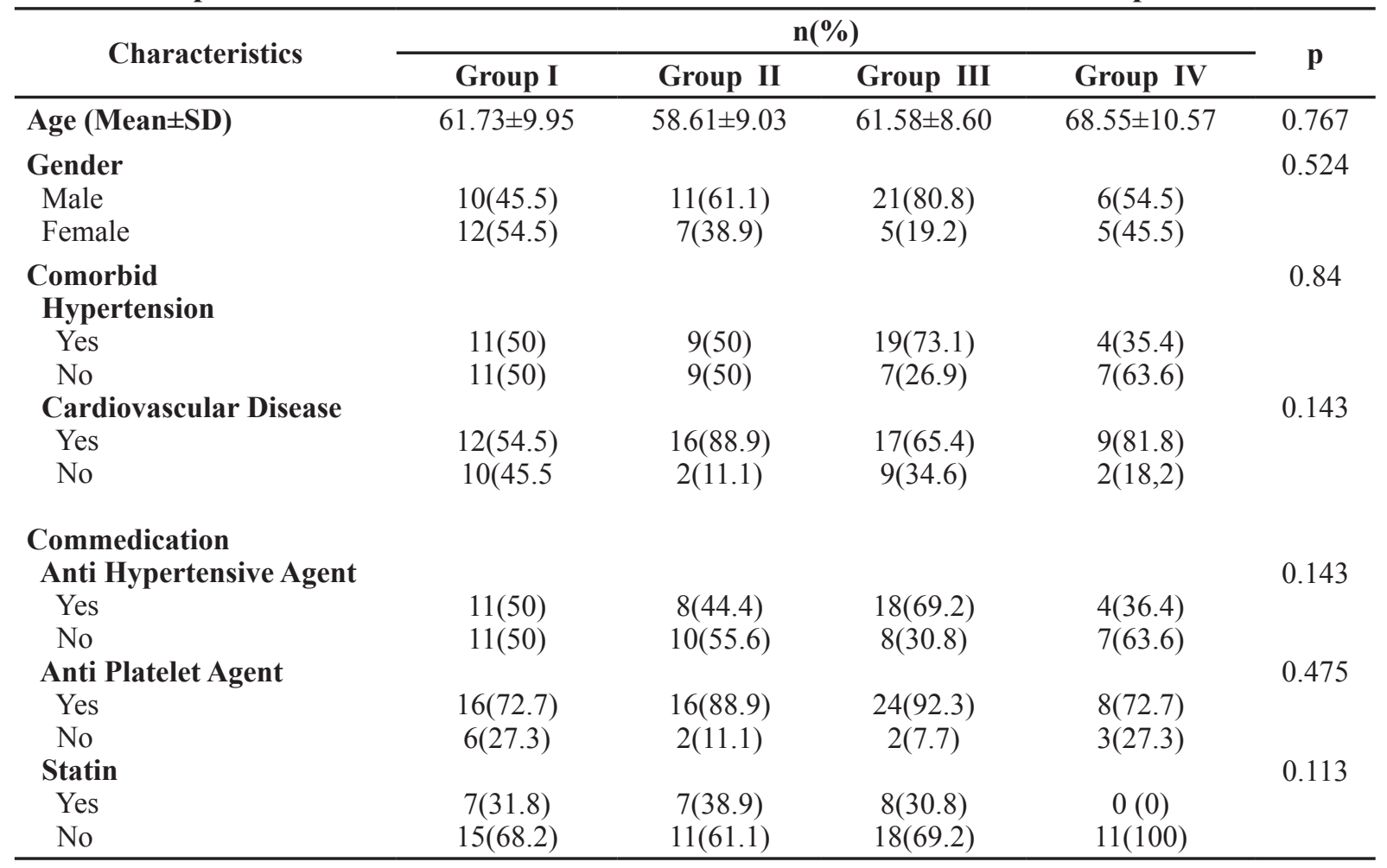

This research was registered at National Institute of Health Research and Development and obtained ethical clearance from the Faculty of Medicine Duta Wacana Christian University, Yogyakarta, Indonesia as the institutional ethics clearance comittee (ethical approval no. 1125/C.16/FK/2019).

\section{Results}

In this study, the data were obtained from 77 subjects. The data of this study were divided into 4 treatment groups, (1) symptomatic therapy only, (2) symptomatic combination therapy with vitamin B, (3) symptomatic combination therapy with vitamin $\mathrm{D}$, and
(4) symptomatic combination therapy with vitamin B-vitamin D. As shown in Table 1, the age of the subjects of this study were in group I $61.73 \pm 9.95$, group II 58.61 \pm 9.03 , group III $61.58 \pm 8.60$, and group IV $68.55 \pm 10.57$. The characteristics of the subjects in this study did not have a significant relationship to the decrease in pain severity $(\mathrm{p}>0.05)$ (Table 1). The results of the average Diabetic Neuropathy Examination (DNE) and Diabetic Neuropathy Symptoms (DNS) assessments with comparable Diabetic Neuropathy Examination (DNE) and Diabetic Neuropathy Symptoms (DNS) results between subjects in each group (Table 2).

As shown in Table 3, assessment of pain

Table 2 Comparison of Diabetic Neuropathy Examination (DNE) and Diabetic Neuropathy Symptoms (DNS) Values between the 4 Groups

\begin{tabular}{lccccc}
\hline & \multicolumn{9}{c}{ Mean \pm SD } & \multirow{2}{*}{ p } \\
\cline { 2 - 5 } & Group I & Group II & Group III & Group IV & \\
\hline DNE & $2.73 \pm 0.985$ & $2.78 \pm 1.00$ & $2.92 \pm 1.13$ & $2.73 \pm 1.01$ & 0.967 \\
DNS & $2.27 \pm 0.63$ & $2.33 \pm 0.84$ & $2.31 \pm 0.68$ & $3.45 \pm 2.25$ & 0.973 \\
\hline
\end{tabular}


Table 3 Comparison of Decrease Pain Scale between 4 Groups

\begin{tabular}{|c|c|c|c|c|c|}
\hline \multirow{2}{*}{$\begin{array}{l}\text { Visual Analogue } \\
\text { Scales Score }\end{array}$} & \multicolumn{4}{|c|}{$\Delta$ Mean $\pm \Delta$ SD } & \multirow{2}{*}{ p } \\
\hline & Group I & Group II & Group III & Group IV & \\
\hline Before therapy & $56.36 \pm 14.65$ & $50.56 \pm 12.11$ & $50.77 \pm 15.98$ & $54.55 \pm 16.35$ & 0.458 \\
\hline Aftre therapy & $42.27 \pm 17.16$ & $13.89 \pm 14.61$ & $19.23 \pm 18.09$ & $7.27 \pm 6.47$ & 0.000 \\
\hline $\begin{array}{l}\text { Difference before } \\
\text { and after }\end{array}$ & $14.09 \pm 5.90$ & $36.67 \pm 7.67$ & $31.54 \pm 15.92$ & $42.27 \pm 16.18$ & 0.000 \\
\hline
\end{tabular}

Table 4 Description of Categorical Pain Levels

\begin{tabular}{|c|c|c|c|c|c|}
\hline \multirow{2}{*}{ Pain Improvement } & \multicolumn{4}{|c|}{$\mathbf{n}(\%)$} & \multirow{2}{*}{$\mathbf{p}$} \\
\hline & Group I & Group II & Group III & Group IV & \\
\hline Pain is greatly reduced $(>50 \%)$ & $0(0)$ & $7(38.9)$ & $7(26.9)$ & $8(72.7)$ & \\
\hline Pain is reduced $(30 \%-50 \%)$ & $4(18.2)$ & $9(50)$ & $13(50)$ & $2(18.2)$ & \\
\hline Pain is slightly $(10 \%-30 \%)$ & $17(77.3)$ & $2(11.1)$ & $6(23.1)$ & $1(9.1)$ & 0.000 \\
\hline Pain does not decrease & $1(4.5)$ & $0(0)$ & $0(0)$ & $0(0)$ & \\
\hline Pain worsens & $0(0)$ & $0(0)$ & $0(0)$ & $0(0)$ & \\
\hline
\end{tabular}

intensity prior to the administration of therapy for group I obtained a mean of $56.36 \pm 14.65$, group II $50.56 \pm 12.11$, group III $50.77 \pm 15.98$ and group IV $54.55 \pm 16.35(\mathrm{p}=0.458)$. After administering the therapy, it was found that the mean decrease in group I was $42.27 \pm 17.16$, group II 13.89 \pm 14.61 , group III 19.23 \pm 18.09 , and group IV $7.27 \pm 6.47(\mathrm{p}=0.000)$. The difference in average pain scale of the 4 groups that experienced the greatest reduction in group IV was $42.27 \pm 16.18$ ( $p=0.000)$.

Pain scale assessment also uses categories.
As shown in Table 4, the category of pain that decreased $>50 \%$ was most experienced in group IV (group with additional therapy of vitamin D and vitamin B) was $72.7 \%$ $(p=0.000)$. Comparison of pain assessment in Table 5 with reduced pain $>30 \%$ was most experienced by the group receiving additional therapy as much as $83.6 \% \quad(\mathrm{p}=0.000)$. The comparison of pain relief in Table 6 with reduced pain $>30 \%$ was more experienced by the group with additional therapy of vitamin $\mathrm{D}$ and vitamin $\mathrm{B}(\mathrm{p}=0.312)$.

Table 5 Comparison of Pain Reduction between Groups that Receive Additional Therapy and Without Additional Therapy

\begin{tabular}{cccccc}
\hline \multirow{2}{*}{ Category } & \multicolumn{4}{c}{ Group Symptomatic } & \multicolumn{2}{c}{ Group Symptomatic+ Add On } & p \\
\cline { 2 - 5 } & $\mathbf{n = 2 2}$ & $\mathbf{\%}$ & $\mathbf{n = 5 5}$ & $\mathbf{\%}$ & \\
\hline Pain reduced $<30 \%$ & 18 & 81.8 & 9 & 16.4 & 0.000 \\
Pain reduced $>30 \%$ & 16 & 88.9 & 20 & 76.9 & \\
\hline
\end{tabular}

Table 6 Comparison of Pain Reduction between Groups Getting Vitamin D Supplementary Therapy and Vitamin B Supplementary Therapy

\begin{tabular}{lccccc}
\hline \multirow{2}{*}{ Category } & \multicolumn{2}{c}{ Group Symptomatic + Vitamin D } & Group Symptomatic + Vitamin B & p \\
\cline { 2 - 5 } & $\mathbf{n = 2 2}$ & $\mathbf{\%}$ & $\mathbf{n}=\mathbf{5 5}$ & $\mathbf{\%}$ & \\
\hline Pain reduced $<30 \%$ & 2 & 11.1 & 6 & 23.1 & 0.312 \\
Pain reduced $>30 \%$ & 16 & 88.9 & 20 & 76.9 & \\
\hline
\end{tabular}




\section{Discussion}

This study aims to measure the reduction in DN pain in patients with type $2 \mathrm{DM}$ who are given additional vitamin $\mathrm{D}$ therapy to standard therapy. After administration of therapy, the smallest average pain scale value obtained by group IV was $7.27 \pm 6.47$. The greatest decrease in pain scale was also experienced by group IV was $42.27 \pm 16.18$. Based on the assessment of the pain scale categories, pain reduction $>50 \%$ is most experienced by group IV as much as $72.7 \%$. Comparison of pain reduction with a limit of $30 \%$ shows that pain reduction $>30 \%$ occurred in the group given symptomatic and additional therapy. The overall results of the smallest mean pain scale after administration of therapy the largest significant reduction in pain scale, the reduction in pain categorically more than $50 \%$ significantly obtained by group IV or combination therapy group vitamin B and vitamin D. With a limit of $30 \%$, the group given additional therapy experienced greater pain reduction.

Ghadiri et al. concluded that hypovitaminosis $\mathrm{D}$ being one of the factors can improve the symptoms and signs of peripheral neuropathy and recommend the provision of vitamin D therapy in patients with type $2 \mathrm{DM}$ with low vitamin D levels..$^{20}$ There are several possible mechanisms of vitamin $\mathrm{D}$ participating in the development of diabetic neuropathy. ${ }^{14}$ Vitamin $\mathrm{D}$ has neurotrophic effects that play a role in nerve function and nerve growth factor (NGF). ${ }^{14}$ Vitamin D may also improve the nociceptors by increasing the pain threshold value where there is a contribution from the effects of antiinflammatory and immunoregulatory effects. ${ }^{14}$

In the inflammatory process, vitamin D will play a role by increasing the regulation of TGF- $\beta 1$ in astrocytes and microglia thereby suppressing cytokine activity. ${ }^{18}$ Other study also showed that vitamin D can reduce levels of inflammatory cytokines such as Prostaglandin
E2 (PGE2), TNF $\alpha$ and Leukotriene B4 (LTB4). ${ }^{15}$

Vitamin D plays a role in the pathogenesis of inflammation, which has a correlation with inflammatory cytokines (IL-13 and IL-17) in the body that influence the development of the emergence of painful DM. ${ }^{16,17}$ The appearance of inflammatory cytokines reflects the presence of low-level inflammation in patients with DM. ${ }^{17}$ The role of vitamin D in its anti-inflammatory effect also by reducing prostaglandin E2 (PGE2) which plays an important role as an inflammatory factor(15). Vitamin $\mathrm{D}$ can reduce nerve threshold by inhibiting COX-2 expression and stimulating 15-prostaglandin dehydrogenase (15-PGDH) which will reduce prostaglandin. ${ }^{18}$ Increased neurotropin synthesis by vitamin D is useful for the development and maintenance of neurons. ${ }^{18}$

Study by Basit et al. (2016) showed treatment with a single dose of 600,000 IU of vitamin $\mathrm{D}$ could be a safe and effective treatment for patients with DN for 20 weeks. ${ }^{21}$ Study by Ghadiri et al. (2019) showed that oral administration of vitamin D3 at a dose of 50,000 IU once a week for 12 weeks can increase serum vitamin D levels and significantly reduce the symptoms and signs of DN. ${ }^{20}$

In general, vitamin $\mathrm{B}$ is also given as a treatment for neuropathy, ${ }^{4,5}$ Vitamin B which is also a neurotropic vitamin has a role to play in maintaining optimal nerve function and assisting in treatment by relieving neuropathy symptom. ${ }^{3}$ Vitamin B has a role as an active coenzyme in metabolic pathways including neurotransmitter syntesis and neuronal membrane synthesis. Therefore, vitamin D and vitamin $\mathrm{B}$ are safe to use as a combination therapy for peripheral neuropathy to maintain nervous system function and reduce pain.

This study has some implications in daily clinical practice. The use of vitamin B and D should be considered as add on therapy for 
patients with painful diabetic neuropathy. Further studies and review are warranted like measure duration of diabetes in each subject to know whether the diabetes is controlled or not. This study did not measure HbAlc so it did not know the average blood glucose level in the last 2-3 months.

\section{Conclusion}

Additional vitamin D therapy in standard therapy for diabetic neuropathy pain gives greater pain reduction compared with standard symptomatic therapy alone.

\section{Funding}

The study was not funded by any source of grants.

\section{Conflict of Interest}

The authors declared no potential conflicts of interest with respect to the research, authorship, and/or publication of this article.

\section{References}

1. International Diabetes Federation. IDF Diabetes Atlas, $8^{\text {th }}$ edition. 2017. [Accessed on: 11 September 2019]. Available at: https://diabetesatlas.org/ upload/resources/previous/files/8/IDF_ DA_8e-EN-final.pdf

2. Alhajraf NM, Alasfour AM. The impact of demographic and academic characteristics on academic performance. Int Bus Res. 2014;7(4):1-17. doi: 10.55 39/ibr.v7n4p92

3. Schloss J, Colosimo M. B vitamin complex and chemotherapy-induced peripheral neuropathy. Curr Oncol Rep. 2017;19(12):76. doi: 10.1007/s11912-01 7-0636-z

4. Hakim M, Kurniani N, Pinzon RT,
Tugasworo D, Basuki M, Haddani H, et al. Management of peripheral neuropathy symptoms with a fixed dose combination of high-dose vitamin B1, B6 and B12: A 12-week prospective non-interventional study in Indonesia. Asian J Med Sci. 2018;9(1):32-40. doi: 10.3126/ajms.v9i1 .18510

5. Geller M, Oliveira L, Nigri R, Mezitis SG, Ribeiro MG, de Souza da Fonseca A, et al. B vitamins for neuropathy and neuropathic pain. Vitam Miner. 2017;6 (2):1000161. doi: 10.4172/2376-1318.10 00161

6. Wimalawansa SJ. Associations of vitamin $\mathrm{D}$ with insulin resistance, obesity, type 2 diabetes, and metabolic syndrome. J Steroid Biochem Mol Biol. 2018;175:177-89. doi: 10.1016/j.jsbmb. 2016.09.017

7. Indra TA, Lydia A, Purnamasari D, Setiati S. Asosiasi antara status vitamin D 25(Oh)D dengan albuminuria pada pasien diabetes melitus tipe 2. J Penyakit Dalam Indones. 2017;4(1):16. doi: 10.7454/jpdi .v4i1.108

8. Niu Y, Li J, Peng R, Zhao X, Wu J, Tang Q. Low vitamin $\mathrm{D}$ is associated with diabetes peripheral neuropathy in older but not in young and middle-aged patients. Diabetes Metab Res Rev. 2019;35(6):e3162. doi: 10.1002/dmrr.3162

9. Peltier A, Goutman SA, Callaghan BC. Painful diabetic neuropathy. Br Med J. 2014;348:g1799. doi: 10.1136/bmj.g1799

10. Javed S, Petropoulos IN, Alam U, Malik RA. Treatment of painful diabetic neuropathy. Ther Adv Chronic Dis. 2015; 6(1):15-28. doi: 10.1177/204062231455 2071

11. Kiraly SJ, Kiraly MA, Hawe RD, Makhani N. Vitamin D as a neuroactive substance: Review. ScientificWorldJournal. 2006;6: 125-39. doi: 10.1100/tsw.2006.25

12. AkyuzG, Sanal-Toprak C, Yagci I, Giray E, 
Kuru-Bektasoglu P. The effect of vitamin D supplementation on pain, quality of life, and nerve conduction studies in women with chronic widespread pain. Int J Rehabil Res. 2017;40(1):76-83. doi: 10.1097/MRR.0000000000000211

13. Wu Z, Malihi Z, Stewart AW, Lawes CMM, Scragg R. Effect of vitamin D supplementation on pain: A systematic review and meta-analysis. Pain Physician. 2016;19(7):415-27.

14. Jung $\mathrm{CH}$, Kim KJ, Kim BY, Kim $\mathrm{CH}$, Kang SK, Mok JO. Relationship between vitamin $\mathrm{D}$ status and vascular complications in patients with type 2 diabetes mellitus. Nutr Res. 2016;36(2): 117-24. doi: 10.1016/j.nutres.2015.11.008

15. Helde-Frankling M, Björkhem-Bergman L. Vitamin D in pain management. Int $\mathrm{J}$ Mol Sci. 2017;18(10):2170. doi: 10.3390/ ijms 18102170

16. Hang H, Yuan S, Yang Q, Yuan D, Liu Q. Multiplex bead array assay of plasma cytokines in type 2 diabetes mellitus with diabetic retinopathy. Mol Vis. 2014; 20:1137-45.

17. Bilir B, Tulubas F, Bilir BE, Atile NS, Kara SP, Yildirim T, et al. The association of vitamin $\mathrm{D}$ with inflammatory cytokines in diabetic peripheral neuropathy. J Phys Ther Sci. 2016;28(7):2159-63. doi: 10.15 89/jpts.28.2159

18. Shipton EA, Shipton EE. Vitamin D and pain: Vitamin D and its role in the aetiology and maintenance of chronic pain states and associated comorbidities. Pain Res Treat. 2015;2015:904967.

19. Bril V, England J, Franklin GM, Backonja M, Cohen J, Del Toro D, et al. Evidence-based guideline: Treatment of painful diabetic neuropathy: Report of the American Academy of Neurology, the American Association of Neuromuscular and Electrodiagnostic Medicine, and the American Academy of Physical Medicine and Rehabilitation. Neurology. 2011;76 (20):1758-65. doi: 10.1212/WNL.0b013 e3182166ebe

20. Ghadiri-Anari A, Mozafari Z, Gholami S, Khodaei SA, Aboutorabi-Zarchi M, Sepehri $\mathrm{F}$, et al. Dose vitamin D supplementations improve peripheral diabetic neuropathy? A before-after clinical trial. Diabetes Metab Syndr Clin Res Rev. 2019;13(1):890-3. doi: 10.1016/ j.dsx.2018. 12.014

21. Basit A, Basit KA, Fawwad A, Shaheen F, Fatima N, Petropoulos IN, et al. Vitamin $\mathrm{D}$ for the treatment of painful diabetic neuropathy. BMJ Open Diabetes Res Care. 2016;4(1):e000148. doi: 10.1136/bmjdrc2015-000148 